\title{
Thermosyntropha tengcongensis sp. nov., a thermophilic bacterium that degrades long-chain fatty acids syntrophically
}

Correspondence

Xiuzhu Dong

dongxz@im.ac.cn

\author{
Fan Zhang, ${ }^{1,2}$ Xiaoli Liu $^{1}$ and Xiuzhu Dong ${ }^{1}$ \\ ${ }^{1}$ State Key Laboratory of Microbial Resources, Institute of Microbiology, Chinese Academy of \\ Sciences, Beijing 100101, PR China \\ ${ }^{2}$ Graduate University, Chinese Academy of Sciences, Beijing 100049, PR China
}

A novel anaerobic, thermophilic, syntrophic, fatty-acid-oxidizing bacterium, strain $L-60^{\top}$, was isolated from a Chinese hot spring. Cells of the strain were non-motile, non-spore-forming, slightly curved rods. Growth occurred between 55 and $70{ }^{\circ} \mathrm{C}$ (optimum about $60{ }^{\circ} \mathrm{C}$ ) and at pH 7.0-9.3 (optimum about $\mathrm{pH}$ 8.2). Crotonate was the only tested carbon source that supported the growth of the strain in pure culture. In co-culture with the thermophilic, hydrogenotrophic Methanothermobacter thermautotrophicus DSM $1053^{\top}$, the isolate could oxidize saturated straight-chain fatty acids with 4-18 carbon atoms, and also unsaturated fatty acids such as oleate, syntrophically. The strain was unable to utilize sulfate, sulfite, thiosulfate, nitrate, fumarate or $\mathrm{Fe}(\mathrm{III})$ as electron acceptors. The major cellular fatty acids were $\mathrm{C}_{14: 0}(35.0 \%), \mathrm{C}_{16: 0}(20.3 \%)$ and iso- $\mathrm{C}_{17: 1}$ l/anteiso- $\mathrm{C}_{17: 1} \mathrm{~B}(30.9 \%)$. The genomic DNA G+C content was $40.3 \mathrm{~mol} \%$. Phylogenetic analysis based on 16S rRNA gene sequences indicated that the strain was affiliated to the family Syntrophomonadaceae and was most closely related to Thermosyntropha lipolytica DSM $11003^{\top}$ (96.7\% similarity). On the basis of phylogenetic and phenotypic evidence, it is proposed that strain $\mathrm{L}-60^{\top}$ represents a novel species, for which the name Thermosyntropha tengcongensis sp. nov. is proposed. The type strain is $\mathrm{L}-60^{\top}\left(=\mathrm{CGMCC} 1.5161^{\top}=\mathrm{JCM}\right.$ $\left.17260^{\top}\right)$.
Fatty acids such as butyrate are important intermediates in the anaerobic degradation of organic matter. As the reactions involved have unfavourable energetics, the fatty acids have to be degraded through a synergetic reaction that involves a partnership between syntrophic fatty-acid-oxidizing bacteria and hydrogen scavengers such as methanogens (Schink, 1992, 1997). To date, 11 syntrophic bacterial species have been described that, when associated with hydrogen-utilizing partners, are able to degrade fatty acids that have 4-18 carbon atoms (McInerney et al., 1979, 1981; Stieb \& Schink, 1985; Roy et al., 1986; Beaty \& McInerney, 1987; Lorowitz et al., 1989; Zhao et al., 1990; Svetlitshnyi et al., 1996; Jackson et al., 1999; Liu et al., 1999; Sekiguchi et al., 2000; Zhang et al., 2004, 2005; Hatamoto et al., 2007; Sousa et al., 2007). The results of physiological characterization and phylogenetic analysis have led to these syntrophic bacteria being considered as two lineages: the family Syntrophomonadaceae (in the phylum Firmicutes) and the family Syntrophaceae (in the class Deltaproteobacteria of the phylum Proteobacteria). Only two thermophilic species of syntrophic

The GenBank/EMBL/DDBJ accession number for the $16 \mathrm{~S}$ rRNA gene of Thermosyntropha tengcongensis $\mathrm{L}-60^{\top}$ is $\mathrm{HM} 807481$.

A supplementary table is available with the online version of this paper. bacteria, Thermosyntropha lipolytica (Svetlitshnyi et al., 1996) and Syntrophothermus lipocalidus (Sekiguchi et al., 2000), have been described so far.

During a survey of the bacterial diversity in a hot spring in Yunnan province, China, we isolated 12 thermophilic bacterial strains, all of which grew well at $60{ }^{\circ} \mathrm{C}$ in prereduced basal medium (McInerney et al., 1979), with a variety of carbon sources. By using butyrate as the sole carbon source, one of these isolates, strain $\mathrm{L}-60^{\mathrm{T}}$, was identified as a thermophilic syntrophic butyrate-degrading bacterium. Phenotypic and phylogenetic characterization indicated that strain $\mathrm{L}-60^{\mathrm{T}}$ represented a novel species of Thermosyntropha.

Throughout the present study, strain L- $60^{\mathrm{T}}$ and Methanothermobacter thermautotrophicus DSM $1053^{\mathrm{T}}$, obtained from Deutsche Sammlung von Mikroorganismen und Zellkulturen (DSMZ), Braunschweig, Germany, were routinely maintained in the pre-reduced basal medium described by McInerney et al. (1979). Thermosyntropha lipolytica DSM $11003^{\mathrm{T}}$ (also from the DSMZ) was cultured as described by Svetlitshnyi et al. (1996). The gas phase was $\mathrm{H}_{2} / \mathrm{CO}_{2}\left(80: 20, \mathrm{v} / \mathrm{v} ; 1.25 \times 10^{5} \mathrm{~Pa}\right)$ for $M$. thermautotrophicus DSM $1053^{\mathrm{T}}$ and $\mathrm{N}_{2}\left(1.01 \times 10^{5} \mathrm{~Pa}\right)$ for the other 
strains. All inoculations and transfers were made with syringes and needles and, unless indicated otherwise, incubations were at $60{ }^{\circ} \mathrm{C}$ in the dark.

In the initial isolation of strain $\mathrm{L}-60^{\mathrm{T}}$, a sediment sample from a hot spring in Tengcong was preserved in a sterile serum bottle that was sealed with a butyl-rubber stopper and then transported to a laboratory. There, the sediment was inoculated into the pre-reduced basal medium with $20 \mathrm{mM}$ butyrate as sole carbon source and incubated at $60{ }^{\circ} \mathrm{C}$. After 10 days, methane production and butyrate degradation were detected in the culture. The culture was subcultured a few times to give an enriched butyratedegrading mixed culture that was then inoculated into Hungate agar roll tubes (Hungate, 1969) with fresh butyrate-supplemented basal medium. After incubation at $60{ }^{\circ} \mathrm{C}$ for 2 weeks, the tubes were found to contain single colonies that fluoresced under light at a wavelength of $420 \mathrm{~nm}$, indicating the presence of a methanogen. The cultures were found to be mixtures of two types of bacterial cell: a $M$. thermautotrophicus-like rod and a slightly curved rod. One of these co-cultures was then inoculated into basal medium with $20 \mathrm{mM}$ crotonate as sole substrate (instead of butyrate) and $10 \mathrm{mM}$ 2-bromoethanesulfonic acid (BrES) added to inhibit the growth of the methanogen. After several subcultures in the crotonate-BrES liquid medium, no methane production could be detected, butyrate and acetate were being produced, and only the slightly curved rods could be observed. After purification of the slightly curved rods, by repeated picking of isolated colonies from the Hungate agar roll tubes, they were named strain $\mathrm{L}-60^{\mathrm{T}}$. The purity of this novel strain was further confirmed by light microscopy and by investigation of the strain's $16 \mathrm{~S}$ rRNA gene sequence in a constructed clone library. The bacteria-specific primer $27 \mathrm{~F}\left(5^{\prime}-\right.$ AGAGTTTGATCMTGGCTCAG-3'), the archaea-specific primer $83 \mathrm{~F}$ ( $5^{\prime}$-ACKGCTCAGTAACAC-3') and the prokaryotic universal primer 1492R (5'-TACGGYTACCTTGTTACGACTT-3') were used to amplify the $16 \mathrm{~S}$ rRNA gene.

The morphology of the cells of strain $\mathrm{L}-60^{\mathrm{T}}$ in the exponential growth phase was studied under a light microscope (BH-2; Olympus) and a transmission electron microscope (H-600A; Hitachi), as described by Zhang et al. (2005). For electron microscopy, some cells were negatively stained with uranyl acetate while others were fixed, embedded, cut into ultrathin sections and then stained with uranyl acetate and lead citrate (Reynolds, 1963). The cells were confirmed to be slightly curved rods, with rounded ends, $0.3-0.4 \mu \mathrm{m}$ wide and $4.5-5.0 \mu \mathrm{m}$ long. They occurred singly and in pairs and chains. Although whole cells stained Gram-negative, their cell walls were found to be Gram-typepositive when examined by transmission electron microscopy (Fig. 1). Spore formation was not observed.

To test the substrate range of strain $\mathrm{L}-60^{\mathrm{T}}$ in pure culture, various compounds including fatty acids and saccharides were added individually to the basal medium, with $T$. lipolytica DSM $11003^{\mathrm{T}}$ similarly tested in parallel experiments.
Growth was monitored by determination of the $\mathrm{OD}_{600}$ of the cultures, with similarly inoculated basal medium used as the blank control. Fermentation products were detected by GC (GC-14B; Shimadzu), as described by Zhang et al. (2004). Crotonate was the only tested substrate that supported the growth of strain $\mathrm{L}-60^{\mathrm{T}}$ in pure culture (Table 1). In contrast, T. lipolytica DSM $11003^{\mathrm{T}}$ could utilize many more substrates (Table 1), confirming the observations of Svetlitshnyi et al. (1996). Stoichiometrically, strain L- $60^{\mathrm{T}}$ converted $17.5 \mathrm{mM}$ crotonate to $5.7 \mathrm{mM}$ butyrate and $18.6 \mathrm{mM}$ acetate in 4 days, indicating electron and carbon recoveries of 83.4 and $85.7 \%$, respectively. Although neither tryptone $(0.05 \%)$ nor peptone $(0.05 \%)$ were required, each stimulated the growth of strain $\mathrm{L}-60^{\mathrm{T}}$. Growth and acid formation were not observed on the following substrates after 2 months: yeast extract $\left(5 \mathrm{~g} \mathrm{l}^{-1}\right)$, peptone $\left(5 \mathrm{~g} \mathrm{l}^{-1}\right)$, Casamino acids $\left(5 \mathrm{~g} \mathrm{l}^{-1}\right)$, betaine $(10 \mathrm{mM})$, pyruvate $(15 \mathrm{mM})$, glucose $\left(5 \mathrm{~g} \mathrm{l}^{-1}\right)$, ribose $\left(2.5 \mathrm{~g} \mathrm{l}^{-1}\right)$, xylose $\left(2.5 \mathrm{~g} \mathrm{l}^{-1}\right)$, glycerol $(20 \mathrm{mM}), \mathrm{H}_{2} / \mathrm{CO}_{2}$ $(80: 20, v / v)$, straight-chain fatty acids from $\mathrm{C}_{2}$ to $\mathrm{C}_{4}$ $(20 \mathrm{mM})$, straight-chain fatty acids from $\mathrm{C}_{5}$ to $\mathrm{C}_{8}(5 \mathrm{mM})$, pelargonate or caprate $\left(5 \mathrm{mM}\right.$ each, with $\left.5 \mathrm{mM} \mathrm{CaCl}_{2}\right)$, laurate, myristate, palmitate, stearate or oleate $(1 \mathrm{mM}$ each, with $\left.1 \mathrm{mM} \mathrm{CaCl}_{2}\right)$, olive oil $\left(5 \mathrm{ml} \mathrm{l}^{-1}\right)$, tributyrin, trilaurin, tripalmitin, tristearin or triolein $(1 \mathrm{mM}$ each, with $3 \mathrm{mM}$ $\left.\mathrm{CaCl}_{2}\right)$, or isobutyrate $(20 \mathrm{mM})$. None of the following compounds was used as an electron acceptor in the oxidation of $20 \mathrm{mM}$ butyrate: sulfate $(20 \mathrm{mM})$, nitrate $(20 \mathrm{mM})$, sulfite $(20 \mathrm{mM})$, thiosulfate $(20 \mathrm{mM})$, fumarate $(20 \mathrm{mM})$ and ferric nitrilotriacetate $(5 \mathrm{mM})$. The growth of strain $\mathrm{L}-60^{\mathrm{T}}$ was strictly anaerobic; no growth occurred in the presence of air.

To determine the substrate utilization of strain $\mathrm{L}-60^{\mathrm{T}}$ in coculture, a culture of the strain grown in basal medium with crotonate was mixed with a $\mathrm{H}_{2} / \mathrm{CO}_{2}$-grown culture of $M$. thermautotrophicus DSM $1053^{\mathrm{T}}$ at a volume ratio of $1: 1$. A

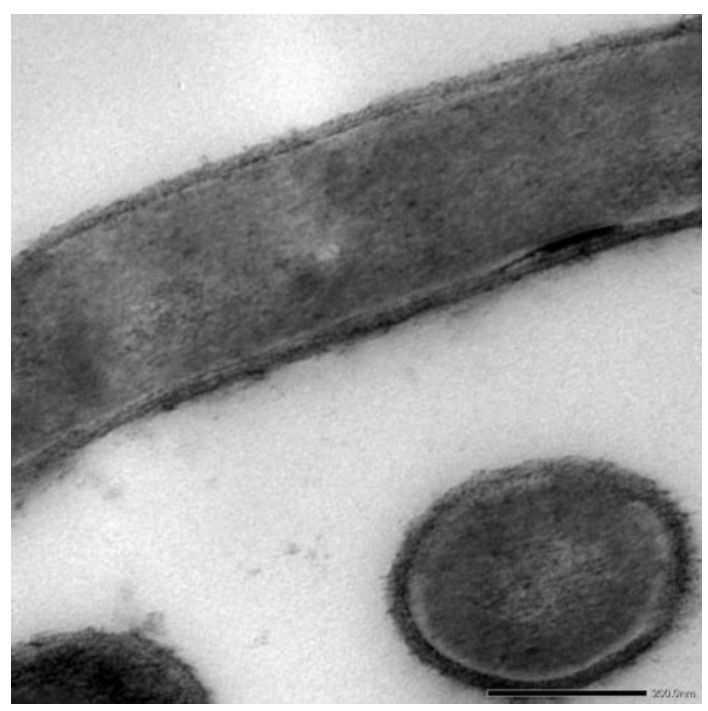

Fig. 1. Transmission electron micrograph of an ultrathin section of cells of strain $L-60^{\top}$. Bar, $0.2 \mu \mathrm{m}$. 
Table 1. Characteristics of strain $L-60^{\top}$ and related type strains in the family Syntrophomonadaceae

Strains: $1, \mathrm{~L}-60^{\mathrm{T}}$ (this study); 2, Thermosyntropha lipolytica DSM $11003^{\mathrm{T}}$ (unless indicated, data from Svetlitshnyi et al., 1996); 3, Syntrophothermus lipocalidus DSM $12680^{\mathrm{T}}$ (Sekiguchi et al., 2000); 4, Syntrophomonas wolfei subsp. wolfei DSM 2245 ${ }^{\mathrm{T}}$ (McInerney et al., 1979, 1981; Beaty \& McInerney, 1987); 5, Syntrophomonas wolfei subsp. saponavida DSM 4212 ${ }^{\mathrm{T}}$ (Lorowitz et al., 1989); 6, Syntrophomonas sapovorans DSM $3441^{\mathrm{T}}$ (Roy $^{2}$ et al., 1986); 7, Syntrophospora bryantii DSM $3014^{\mathrm{T}}$ (Stieb \& Schink, 1985; Zhao et al., 1990). +, Positive; -, negative; ND, no data available.

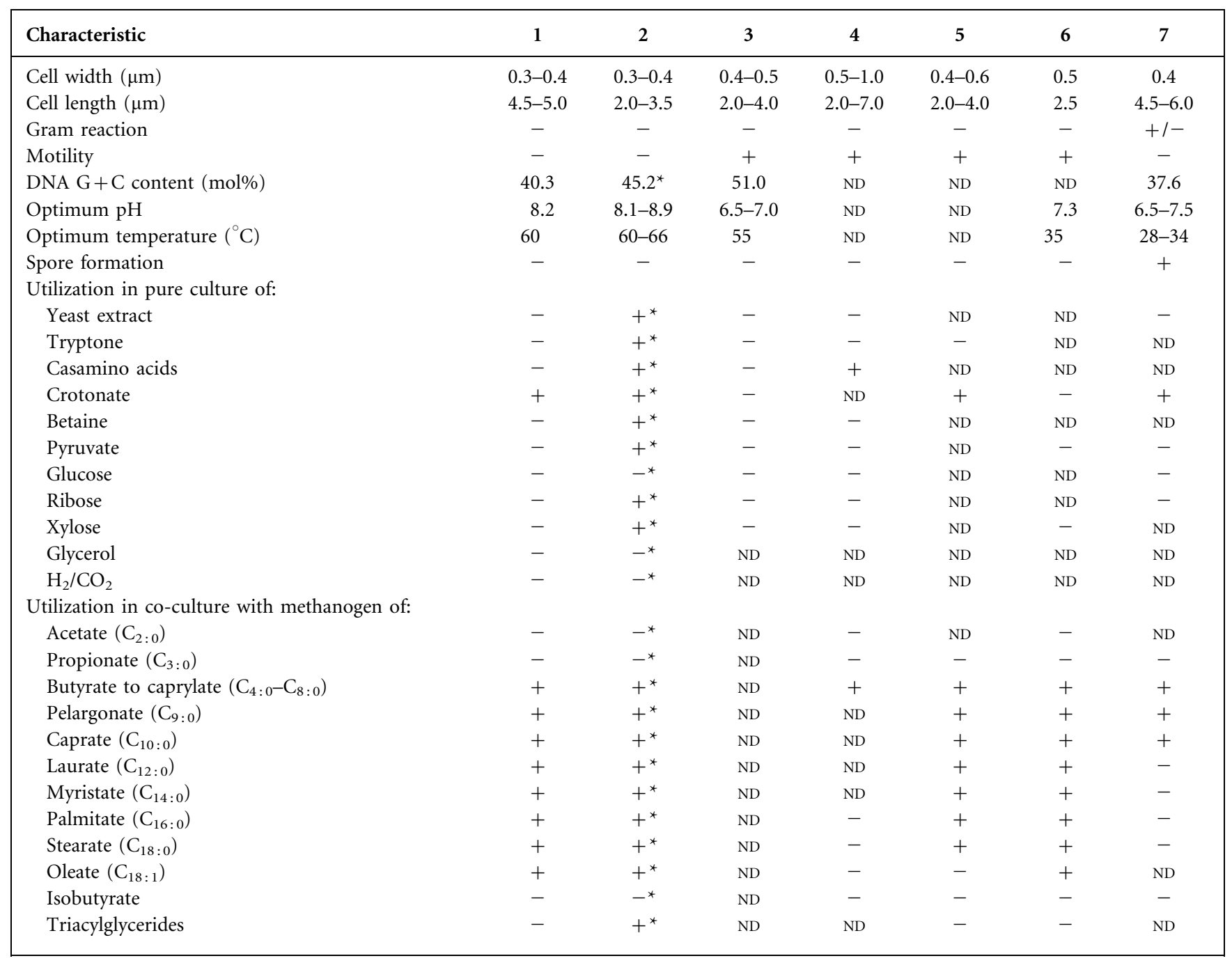

${ }^{\star}$ Data from this study.

similar co-culture of T. lipolytica DSM $11003^{\mathrm{T}}$ with $M$. thermautotrophicus DSM $1053^{\mathrm{T}}$ was constructed and tested in a parallel experiment. With the co-cultures containing strain $\mathrm{L}-60^{\mathrm{T}}$, methane production was only detected, after 2 months of cultivation, when butyrate, a straight-chain fatty acid from $\mathrm{C}_{5}$ to $\mathrm{C}_{8}$, pelargonate, caprate, laurate, myristate, palmitate, stearate or oleate was added to the basal medium, as substrate (Table 1). When cultured with $M$. thermautotrophicus DSM $1053^{\mathrm{T}}$, strain $\mathrm{L}-60^{\mathrm{T}}$ converted $20 \mathrm{mM}$ butyrate into $38 \mathrm{mM}$ acetate and $4.6 \mathrm{mM}$ methane within 20 days. While fatty acids with even numbers of carbon atoms were degraded into just acetate and methane, those with odd numbers of carbon atoms were converted into acetate, propionate and methane, indicating that strain $\mathrm{L}-60^{\mathrm{T}}$ subjected fatty acids to $\beta$-oxidation.

Cultures in basal medium containing $20 \mathrm{mM}$ crotonate, each set up using a $2 \%(\mathrm{v} / \mathrm{v})$ inoculum, were used to investigate the $\mathrm{pH}$ and temperature ranges for the growth of strain L- $60^{\mathrm{T}}$. Growth was again evaluated, after various periods of incubation, as $\mathrm{OD}_{600}$. To explore the effects of $\mathrm{pH}$, the initial $\mathrm{pH}$ of medium was adjusted to $4.3-10.0$ by addition of $\mathrm{HCl}$ or $\mathrm{NaOH}$ under an atmosphere of pure $\mathrm{N}_{2}$ at room temperature, before the medium was inoculated with the novel strain and incubated at $60{ }^{\circ} \mathrm{C}$. To determine the optimum temperature for growth, cultures were 
incubated at $18,37,45,55,60,65,70,75$ and $80{ }^{\circ} \mathrm{C}$. Growth occurred at $\mathrm{pH} 7.0-9.3$ (optimum about $\mathrm{pH}$ 8.2) and between 55 and $70{ }^{\circ} \mathrm{C}$ (optimum about $60{ }^{\circ} \mathrm{C}$ ). Under optimal conditions $\left(\mathrm{pH} 8.2\right.$ and $\left.60{ }^{\circ} \mathrm{C}\right)$, the $\mathrm{OD}_{600}$ of a pure culture of strain $\mathrm{L}-60^{\mathrm{T}}$ in the basal medium with $20 \mathrm{mM}$ crotonate increased by about $0.3 \mathrm{~h}^{-1}$. The corresponding rate for T. lipolytica DSM $11003^{\mathrm{T}}$ (about $0.7 \mathrm{~h}^{-1}$ ) was of the same order of magnitude.

The effects of antibiotics on growth of strain $\mathrm{L}-60^{\mathrm{T}}$ were tested at $\mathrm{pH} 8.2$ and $60{ }^{\circ} \mathrm{C}$, using $10 \mathrm{mM}$ crotonate as substrate and a $2 \%(\mathrm{v} / \mathrm{v})$ inoculum. As growth was inhibited completely by ampicillin, chloramphenicol, kanamycin, neomycin, rifampicin or vancomycin (each at $50 \mu \mathrm{g}$ $\mathrm{ml}^{-1}$ ), the cells of the strain probably have a Gram-typepositive cell wall.

The cellular fatty acids of strain L- $60^{\mathrm{T}}$ and T. lipolytica DSM $11003^{\mathrm{T}}$ were extracted, methylated and analysed as described in the standard protocol of the Sherlock Microbial Identification System (Sasser, 2001), except that both strains were grown in crotonate-supplemented liquid medium and incubated at $60{ }^{\circ} \mathrm{C}$ until they reached the late-exponential phase of growth. The major cellular fatty acids of strain L$60^{\mathrm{T}}$ were $\mathrm{C}_{14: 0}(35.0 \%), \mathrm{C}_{16: 0}(20.3 \%)$ and iso- $\mathrm{C}_{17: 1} \mathrm{I} /$ anteiso- $\mathrm{C}_{17: 1} \mathrm{~B}(30.9 \%)$, whereas $\mathrm{C}_{14: 0}(26.5 \%), \mathrm{C}_{16: 0}$ $(21.0 \%)$ and iso- $\mathrm{C}_{15: 1} \mathrm{H} / \mathrm{C}_{13: 0} 3-\mathrm{OH}(12.4 \%)$ were the predominant cellular fatty acids of T. lipolytica DSM $11003^{\mathrm{T}}$ (Table S1, available in IJSEM Online).

The method described by Marmur (1961) was used to extract genomic DNA from the cells of strain $\mathrm{L}-60^{\mathrm{T}}$ and $T$. lipolytica DSM $11003^{\mathrm{T}}$ that had been grown in crotonatesupplemented basal medium. By using HPLC (Mesbah et al., 1989), with Escherichia coli K-12 as a reference, the G +C contents of the genomic DNA of strain $\mathrm{L}-60^{\mathrm{T}}$ and $T$. lipolytica DSM $11003^{\mathrm{T}}$ were determined to be 40.3 and $45.2 \mathrm{~mol} \%$, respectively.

The 16S rRNA gene of strain L- $60^{\mathrm{T}}$ was amplified by PCR, using the $27 \mathrm{~F}$ and $1492 \mathrm{R}$ primers, and then sequenced by the BioSune Company (Beijing, China). The BLAST algorithm was used to search GenBank for similar sequences, before CLUSTAL_X (Thompson et al., 1994) was employed to align the best matching sequences and evaluate their levels of similarity. Based on a consensus length of the $16 \mathrm{~S}$ rRNA gene sequences (1410 nt), a neighbour-joining phylogenetic tree (Fig. 2) rooted with Clostridium butyricum ATCC 43755 was constructed, using the MEGA4 package (Tamura et al., 2007). This tree indicated that Thermosyntropha lipolytica DSM $11003^{\mathrm{T}}$ was most closely related to strain $\mathrm{L}-60^{\mathrm{T}}$ (96.7\% sequence similarity).

Using a spectrophotometer (UV800; Beckman) and the initial reassociation rates at $61-65^{\circ} \mathrm{C}$, as described by Owen \& Pitcher (1985), the level of DNA-DNA relatedness between strain L-60 ${ }^{\mathrm{T}}$ and T. lipolytica DSM $11003^{\mathrm{T}}$ was determined to be $44.0 \%$.

Although the phenotypic and phylogenetic data indicate that strain $\mathrm{L}-60^{\mathrm{T}}$ should be assigned to the genus Thermosyntropha, the novel strain can be distinguished from the only species currently recognized in this genus ( $T$. lipolytica). Strain $\mathrm{L}-60^{\mathrm{T}}$ can only grow on crotonate in pure culture, whereas T. lipolytica can use several substrates, including yeast extract and tryptone. Although T. lipolytica can hydrolyse lipids, forming fatty acids and glycerol, strain L$60^{\mathrm{T}}$ lacks this ability. Finally, the DNA $\mathrm{G}+\mathrm{C}$ content of strain $\mathrm{L}-60^{\mathrm{T}}$ is lower by $5 \mathrm{~mol} \%$ than that of the type strain of $T$. lipolytica grown under the same conditions. Based on the phylogenetic and phenotypic evidence, we propose that strain $\mathrm{L}-60^{\mathrm{T}}$ represents a novel species of Thermosyntropha, for which the name Thermosyntropha tengcongensis sp. nov. is proposed.

\section{Description of Thermosyntropha tengcongensis sp. nov.}

Thermosyntropha tengcongensis (teng.con.gen'sis. N.L. fem. adj. tengcongensis referring or pertaining to Tengcong, China, where the type strain was isolated).

Cells are non-motile, Gram-staining-negative, slightly curved rods, $0.3-0.4 \mu \mathrm{m}$ wide and $4.5-5.0 \mu \mathrm{m}$ long, that occur singly or in pairs or chains. Spores were not observed. Grows on crotonate in pure culture but not on yeast extract, tryptone, Casamino acids, betaine, pyruvate, ribose or xylose. In syntrophic association with hydrogenotrophic methanogens, the organism can utilize saturated straight-chain fatty acids with 4-18 carbon atoms as well as unsaturated fatty acids such as oleate, but not triglycerides. Growth occurs between 55 and $70{ }^{\circ} \mathrm{C}$ (optimum about $60{ }^{\circ} \mathrm{C}$ ) and at $\mathrm{pH}$ 7.0-9.3 (optimum about $\mathrm{pH}$ 8.2). The major cellular fatty acids are $\mathrm{C}_{14: 0}, \mathrm{C}_{16: 0}$ and iso- $\mathrm{C}_{17: 1} \mathrm{I} /$ anteiso- $\mathrm{C}_{17: 1} \mathrm{~B}$.

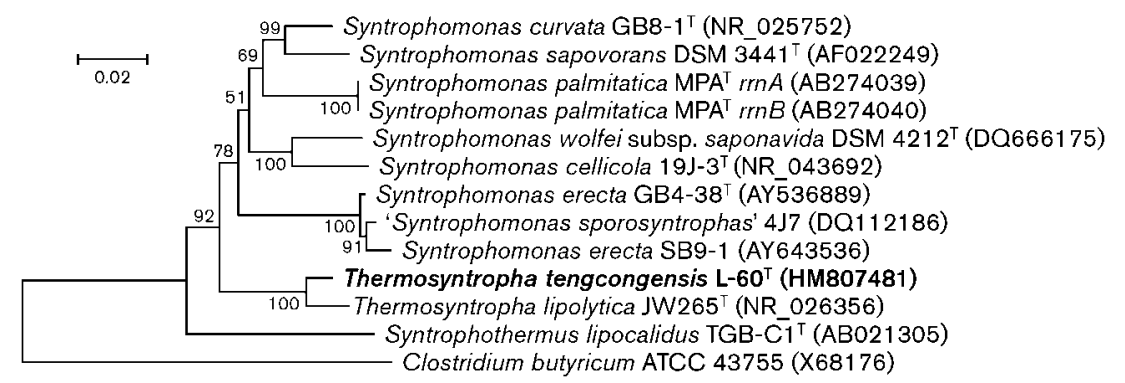

Fig. 2. Neighbour-joining phylogenetic tree based on 16S rRNA gene sequences (a consensus length of $1410 \mathrm{nt}$ ), showing the relationships of strain $L-60^{\top}$ and related taxa. Numbers at nodes indicate percentages of bootstrap support, based on analysis of 1000 resampled datasets. The sequence of Clostridium butyricum ATCC 43755 was used as an outgroup. Bar, 0.02 substitutions per nucleotide position. 
The type strain, $\mathrm{L}-60^{\mathrm{T}}\left(=\mathrm{CGMCC} 1.5161^{\mathrm{T}}=\mathrm{JCM} 17260^{\mathrm{T}}\right)$, was isolated from a sediment sample collected from a hot spring in the Chinese town of Tengcong. The DNA G $+\mathrm{C}$ content of the type strain is $40.3 \mathrm{~mol} \%$.

\section{Acknowledgements}

This study was supported by the grants from the National Science Foundation of China $(30830007,30621005)$.

\section{References}

Beaty, P. S. \& McInerney, M. J. (1987). Growth of Syntrophomonas wolfei in pure culture on crotonate. Arch Microbiol 147, 389-393.

Hatamoto, M., Imachi, H., Fukayo, S., Ohashi, A. \& Harada, H. (2007). Syntrophomonas palmitatica sp. nov., an anaerobic, syntrophic, long-chain fatty-acid-oxidizing bacterium isolated from methanogenic sludge. Int J Syst Evol Microbiol 57, 2137-2142.

Hungate, R. E. (1969). A roll tube method for cultivation of strict anaerobes. Methods Microbiol 3B, 117-132.

Jackson, B. E., Bhupathiraju, V. K., Tanner, R. S., Woese, C. R. \& Mclnerney, M. J. (1999). Syntrophus aciditrophicus sp. nov., a new anaerobic bacterium that degrades fatty acids and benzoate in syntrophic association with hydrogen-using microorganisms. Arch Microbiol 171, 107-114.

Liu, Y., Balkwill, D. L., Aldrich, H. C., Drake, G. R. \& Boone, D. R. (1999). Characterization of the anaerobic propionate-degrading syntrophs Smithella propionica gen. nov., sp. nov. and Syntrophobacter wolinii. Int J Syst Bacteriol 49, 545-556.

Lorowitz, W. H., Zhao, H. \& Bryant, M. P. (1989). Syntrophomonas wolfei subsp. saponavida subsp. nov., a long-chain-fatty-acid-degrading, anaerobic syntrophic bacterium; Syntrophomonas wolfei subsp. wolfei subsp. nov.; and emended descriptions of the genus and species. Int J Syst Bacteriol 39, 122-126.

Marmur, J. (1961). A procedure for the isolation of deoxyribonucleic acid from microorganisms. J Mol Biol 3, 208-218.

McInerney, M. J., Bryant, M. P. \& Pfennig, N. (1979). Anaerobic bacterium that degrades fatty acids in syntrophic association with methanogens. Arch Microbiol 122, 129-135.

Mclnerney, M. J., Bryant, M. P., Hespell, R. B. \& Costerton, J. W. (1981). Syntrophomonas wolfei gen. nov. sp. nov., an anaerobic, syntrophic, fatty acid-oxidizing bacterium. Appl Environ Microbiol 41, 1029-1039.

Mesbah, M., Premachandran, U. \& Whitman, W. B. (1989). Precise measurement of the $\mathrm{G}+\mathrm{C}$ content of deoxyribonucleic acid by highperformance liquid chromatography. Int J Syst Bacteriol 39, 159-167.

Owen, R. J. \& Pitcher, D. (1985). Current methods for estimating DNA base composition and levels of DNA-DNA hybridization. In
Chemical Methods in Bacterial Systematics, pp. 67-93. Edited by M. Goodfellow \& D. E. Minnikin. London: Academic Press.

Reynolds, E. S. (1963). The use of lead citrate at high $\mathrm{pH}$ as an electron-opaque stain in electron microscopy. J Cell Biol 17, 208212.

Roy, F., Samain, E., Dubourguier, H. \& Albagnac, G. (1986). Syntrophomonas sapovorans sp. nov., a new obligately proton reducing anaerobe oxidizing saturated and unsaturated long chain fatty acids. Arch Microbiol 145, 142-147.

Sasser, M. (2001). Identification of bacteria by gas chromatography of cellular fatty acids, MIDI Technical Note 101. Newark, DE: MIDI Inc.

Schink, B. (1992). Syntrophism among prokaryotes. In The Prokaryotes, 2nd edn, pp. 276-299. Edited by A. Balows, H. G. Trüper, M. Dworkin, W. Harder \& K. H. Schleifer. New York: Springer.

Schink, B. (1997). Energetics of syntrophic cooperation in methanogenic degradation. Microbiol Mol Biol Rev 61, 262-280.

Sekiguchi, Y., Kamagata, Y., Nakamura, K., Ohashi, A. \& Harada, H. (2000). Syntrophothermus lipocalidus gen. nov., sp. nov., a novel thermophilic, syntrophic, fatty-acid-oxidizing anaerobe which utilizes isobutyrate. Int J Syst Evol Microbiol 50, 771-779.

Sousa, D. Z., Smidt, H., Alves, M. M. \& Stams, A. J. M. (2007). Syntrophomonas zehnderi sp. nov., an anaerobe that degrades longchain fatty acids in co-culture with Methanobacterium formicicum. Int J Syst Evol Microbiol 57, 609-615.

Stieb, M. \& Schink, B. (1985). Anaerobic oxidation of fatty acids by Clostridium bryantii sp. nov., a sporeforming, obligately syntrophic bacterium. Arch Microbiol 140, 387-390.

Svetlitshnyi, V., Rainey, F. \& Wiegel, J. (1996). Thermosyntropha lipolytica gen. nov., sp. nov., a lipolytic, anaerobic, alkalitolerant, thermophilic bacterium utilizing short- and long-chain fatty acids in syntrophic coculture with a methanogenic archaeum. Int J Syst Bacteriol 46, 1131-1137.

Tamura, K., Dudley, J., Nei, M. \& Kumar, S. (2007). MEGA4: molecular evolutionary genetics analysis (MEGA) software version 4.0. Mol Biol Evol 24, 1596-1599.

Thompson, J. D., Higgins, D. G. \& Gibson, T. J. (1994). CLUSTAL W: improving the sensitivity of progressive multiple sequence alignment through sequence weighting, position-specific gap penalties and weight matrix choice. Nucleic Acids Res 22, 4673-4680.

Zhang, C., Liu, X. \& Dong, X. (2004). Syntrophomonas curvata sp. nov., an anaerobe that degrades fatty acids in co-culture with methanogens. Int J Syst Evol Microbiol 54, 969-973.

Zhang, C., Liu, X. \& Dong, X. (2005). Syntrophomonas erecta sp. nov., a novel anaerobe that syntrophically degrades short-chain fatty acids. Int J Syst Evol Microbiol 55, 799-803.

Zhao, H. X., Yang, D. C., Woese, C. R. \& Bryant, M. P. (1990). Assignment of Clostridium bryantii to Syntrophospora bryantii gen. nov., comb. nov. on the basis of a $16 \mathrm{~S}$ rRNA sequence analysis of its crotonate-grown pure culture. Int J Syst Bacteriol 40, 40-44. 